\title{
Defining and assessing vulnerability within law enforcement and public health organisations: a scoping review
}

\author{
Iniobong Enang ${ }^{1 *}$, Jennifer Murray ${ }^{1}$, Nadine Dougall ${ }^{1}$, Andrew Wooff ${ }^{2}$ Inga Heyman ${ }^{1}$ and Elizabeth Aston ${ }^{2}$
}

\begin{abstract}
Background: Historically, police departments focused solely on criminal justice issues. Recently, there has been a dynamic shift in focus, with Law Enforcement professional groups assuming more responsibility for tackling mental health and distress-related issues (that may arise because of mental health related problems and learning disabilities) alongside Public Health departments. While Law Enforcement has become a 'last line of support' and an increasing partner in mental health support, there is partnership working between law enforcement, psychology, and health professions in training and mental health service delivery. The term vulnerability is frequently used across Law Enforcement and Public Health (LEPH) to identify those in need of these services. Effective vulnerability assessment is therefore expected to prevent unintentional harmful health and criminal justice consequences and manage the negative impact of such in cases where prevention is not possible. This scoping review aimed to identify how vulnerability is defined and assessed across LEPH organisations.

Results: Vulnerability is context-specific from a Law Enforcement perspective, and person-specific from a Public Health perspective. Definitions of vulnerability are at best fragmented, while models for assessing vulnerability lack uniformity across LEPH. The implications are two-fold. For "vulnerable groups", the lack of an evidence-based definition and assessment model could prevent access to relevant LEPH services, exacerbating issues of multiple vulnerabilities, co-morbidity, and/or dual diagnosis. All could inadvertently enable social exclusion of vulnerable groups from political discourse and policy interventions. The lack of consistency regarding vulnerability may result in reactive crisis responses as opposed to proactive preventative measures.

Conclusions: This scoping review exposes the complexities associated with defining and assessing vulnerability from a LEPH perspective, which are perceived and prioritised differently across the organizations. Future research must bridge this gap. Building on the establishment of a definition of vulnerability within the empirical literature, researchers ought to engage with service users, LEPH staff, and those engaged in policy making to craft effective vulnerability definitions and assessment models. Only through evidence based, co-produced definitions and assessment models for vulnerability can we ensure that best-practice, but also meaningful and feasible practice, in vulnerability assessment can be achieved.
\end{abstract}

Keywords: Law enforcement, Public health, Policing, Vulnerability, Vulnerability assessment

\footnotetext{
*Correspondence: i.enang@napier.ac.uk

'School of Health \& Social Care, Edinburgh Napier University, Sighthill

Campus, Sighthill Court, Edinburgh EH11 4BN, Scotland, UK

Full list of author information is available at the end of the article
}

(c) The Author(s). 2019 Open Access This article is distributed under the terms of the Creative Commons Attribution 4.0 International License (http://creativecommons.org/licenses/by/4.0/), which permits unrestricted use, distribution, and reproduction in any medium, provided you give appropriate credit to the original author(s) and the source, provide a link to the Creative Commons license, and indicate if changes were made. 


\section{Background}

There is increasing international recognition that greater emphasis on partnership working across the intersect of policing and public health is a necessity (Police Scotland, 2017; Punch \& James, 2017). Despite the different contexts in which policing (traditionally linked to criminal justice and establishing law and order) and public health (provision of physical, mental, and social well-being) operate, both fields share similar complex challenges; necessitating closer partnership working between them (Van Dijk \& Crofts, 2017). One of these complex challenges relates to vulnerability.

Vulnerability has been defined in different ways, depending upon the field and literature being discussed. One example which offers an 'all encompassing' perspective outlines vulnerability as a state or condition whereby a person is in danger, under threat, experiencing health challenges, at risk, and/or requiring support/ protection (Larkin, 2009). This definition suggests, then, that anyone can be vulnerable at any point in time, and that vulnerability is not a stable state across situations and the lifespan. While this is a useful way to consider vulnerability - as a holistic, variable construct - it may be considered too broad a construct to then develop assessment strategies and protocols, form policies, and indeed understand within the specific remit of law enforcement and public health.

Vulnerability is a key concern across policing and public health partners (Murray et al., 2018), with increasing prioritisation being given to the identification, assessment, and management of vulnerable victims and perpetrators of crime (College of Policing, 2018; Department of Health, 2014). Indeed, Police Scotland Strategy 2026 notes that top priority is to protect vulnerable people (Police Scotland, 2017). Despite this, there appears to be no unified definition of vulnerability across policing and public health practices, or within the policy documentation or literature. This, then, inhibits our understandings of what vulnerability means at the intersect of policing and public health, and makes the identification, assessment, and management of vulnerable people challenging for police and health professionals. Equally, should a unified understanding and shared definition of vulnerability be established and adopted across the intersect of policing and public health, communication, decision making, and management of vulnerable people with complex needs across the criminal justice and health systems could be improved.

The current scoping review aims to identify how vulnerability is defined and assessed in relation to the adult population across Law Enforcement and Public Health (LEPH). It focuses on collaborative partnership working across LEPH. For the purposes of the current review, we will use 'Law Enforcement' in a broad sense, recognising that the role of law and policing professionals is much broader than enforcement. We therefore adopt the broader context of the role, including working with the public and other partners, community engagement, etc. Public Health, again, adopts a broad definition, including any health and social care professional who works with individuals who could be considered or who consider themselves as vulnerable.

Scoping reviews are conducted for a variety of reasons including: conceptual mapping ${ }^{1}$ (Anderson et al., 2008); literature mapping ${ }^{2}$ (Anderson et al., 2008; Ehrich et al., 2002); policy mapping ${ }^{3}$ (Anderson et al., 2008); and identification of research gaps (Arksey \& O'Mally, 2005), including the extent and nature of research evidence (Grant et al., 2009). From a LEPH perspective, the current review was required and carried out to address three interrelated issues. First, to conceptually map and lend understanding to how the term 'vulnerability' is defined and the context in which it is used in different countries and LEPH organizations (Anderson et al, 2008). Second, to identify the models or methods of vulnerability assessment as presented in these documents (Grant et al., 2009). Building on the first and second aims, the third seeks to identify under-researched areas within the context of vulnerability assessment in LEPH (Ehrich et al., 2002) to identify key research priorities for future research in vulnerability and assessment across LEPH.

The selected methodological approach aligns with Arksey and O'Mally's (2005) six stage framework, and incorporates recommendations provided by Levac et al. (2010). The stages of the framework are: identifying a research question; finding appropriate studies; selecting the studies; conducting content analysis via the synthesis and interpretation of qualitative data; organizing, summarizing and recording results; and stakeholder consultation. Discussions within the current review are structured according to these sections for the readers' ease.

\section{Methods}

\section{Stage 1: Identifying a research question}

The central research question for the current review asks: "What can we learn from extant literature about how LEPH professional groups define and assess vulnerability within the adult population?"

The central research question was divided into two sub-questions to ensure that the critical elements (vulnerability definition and vulnerability assessment) of the study were effectively addressed:

1. From a LEPH perspective how is vulnerability defined within the adult population? 
2. Considering this demographic, do models for vulnerability assessment exist within or across LEPH professional groups?

\section{Stage 2: Finding appropriate studies}

Following the identification of the research question and sub-questions, the next step entailed finding appropriate studies. To this end, inclusion and exclusion criteria were developed as presented in Fig. 1 and Table 1.

\section{Inclusion criteria}

As indicated in Table 1, articles included for review were published in English, between the years 2000-2018. The year 2000 was selected because the Adults with Incapacity (Scotland) Act 2000 was passed then (The Scottish Government, 2008) and the research team are based within Scotland hence its contextual relevance.
The date of publication of this legislation in Scotland was key as it led the way towards recognising the limitations faced by adults with mental health challenges across LEPH contexts. It is instrumental to the current review because mental health problems are associated with vulnerability across LEPH organizations, although it must be acknowledged that mental health problems are not to be viewed as synonymous with vulnerability, as detailed in the Adult Support and Protection Act (2007) (The Scottish Government, 2018). The years 2010 and 2013 were also of particular relevance to the current review from a healthcare and emergency services policy perspective.

The year 2010 was selected because from a Public Health perspective, the Healthcare Quality Strategy for NHS Scotland was published then. This strategy promotes partnership working between key NHS stakeholders

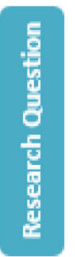

How is vulnerability defined and assessed by LEPH professional groups?

Records identified through database searching

( $n=155$ )

- EBSCO CINAHL

- ebsco medLINe

- EBSCO PsyclNFo

- Proquest Criminology Collection

- Proquest Sociology Collection

Inclusion Criteria

Articles:

- published between 2000 and 2018;

- published in English;

- Peer revievied;

- LEPH professional groups;

- All adult population

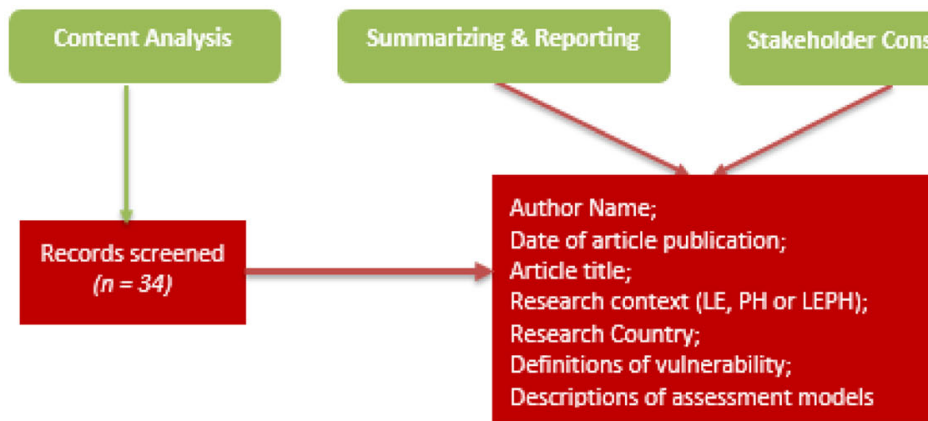

Records excluded $(n=113)$ Articles:

- published before 2000 ;

- focusing on people under 18;

- without ref to LEPH Abstracts without ref to LEPH Records after 8 duplicates removed $(n=147)$ 
Table 1 Inclusion and Exclusion Criteria

\begin{tabular}{ll}
\hline Inclusion Criteria & Exclusion criteria \\
\hline Articles published in English & $\begin{array}{c}\text { Articles published in a language other } \\
\text { than English }\end{array}$ \\
Articles published between 2000 and 2018 & Articles published before 2000 \\
Articles discussing vulnerability and vulnerability assessment & Abstracts without reference to \\
vulnerability & Children and young people below 18 \\
All adult population (> 18 y/o) & years old \\
LEPH professional groups in any country & Articles without references to LEPH \\
& professional groups \\
Articles retrieved from five key databases: Cumulative Index of Nursing and Allied Health Literature & Book chapters and non-peer reviewed \\
(CINAHL), Medical Literature Analysis and Retrieval System Online (MEDLINE), Psychological Information & articles \\
Database (PsycINFO), Criminology Collection, and Sociology Collection &
\end{tabular}

including service users (patients, carers, general public) and service providers (local authorities, third sector and the NHS). It aims to provide excellent health services to service users in Scotland (The Scottish Government, 2010). Similarly, the Police and Fire Reform (Scotland) 2012 Act was operational in 2013 and involved merging of policing, and fire and rescue services (The Scottish Parliament, 2012). The reform aims to ensure increased equity of access to specialised services while protecting and enhancing service delivery; improve national capacity in times of crises (for example flooding); and strengthening relationships between service users and providers by promoting the engagement of local councillors in designing and integrating local services with communities (The Scottish Government, 2017). Furthermore, the purpose of policing enshrined within the Police and Fire Reform Scotland Act (2012) is to improve safety and wellbeing by working in collaboration with others, further emphasising the need for shared understandings across working partners in LEPH.

In line with the research question and sub-questions, the articles selected were limited to those which discussed vulnerability including its assessment. This was considered within the context of LEPH. Vulnerability is perceived differently in children and adults within legal definitions. Therefore, focusing on a specific demographic, namely the adult population prevented ambiguity in the research results. While in Scotland, the legislation considers vulnerable adults to be those aged 16 years and over (Adult Support and Protection Act, 2007), this is not the commonly held stance on adulthood internationally, with the majority of countries considering adulthood as 18 years and older. We therefore decided to adopt the wider-adopted 18 years and older definition within the current scoping review to allow international consistency across the literature searching and inclusion. CINAHL, MEDLINE, PsycINFO, Criminology Collection, and Sociology Collection were selected as key databases because they contain articles that address LEPH matters.

\section{Exclusion criteria}

This research is targeted at a global audience including LEPH departments, governments/policy makers, and academic researchers. Accordingly, the research findings are intended to:

- Raise global awareness of issues relating to vulnerability identification and assessment across LEPH departments. Since vulnerability assessment is a growing concern across LEPH departments, we believe that it is more expedient to focus on findings from contemporary studies which might reflect this new reality; hence the exclusion of papers published before the year 2000;

- Guide Governments in strategic decision-making. As government policies and strategic plans typically span a 10-year period, it is necessary to consider contemporary studies focusing on vulnerability definitions and assessments. This is another reason why we excluded papers published prior to 2000 .

To some extent, some of the other exclusion criteria (articulated next) constitute research limitations. First, articles published in a language other than English were excluded. This was due to funding and time limitations, including the lack of a multi-lingual member in our six member research team. In so doing, we acknowledge that some relevant papers may have been excluded.

Second, the adult age as articulated in the exclusion criteria, is from 18 years and above. As the Adult Support and Protection Legislation in Scotland categorises people from 16 years and above as adults (Care Information Scotland, 2018), the findings of this review may exclude young adults between 16 years old and those just under 18 years old; constituting a limitation. However, as detailed earlier, the need to consider the international context, rather than only the local context of the authors, was considered desirable for the current review, and as the majority of international legislation considers 
adulthood to begin at 18 years old, we chose this upper threshold. That said, we would encourage future authors to consider carefully whether to expand the definition of adulthood to begin at 16 years old. Similarly, grey literature was not included because these are not usually peer reviewed.

Third, articles that did not explicitly mention the word 'vulnerability' in their abstract were excluded. As our key focus was on vulnerability, we felt that articles that did not mention vulnerability specifically in their abstract might not discuss vulnerability as thoroughly as required to address out research question. The key purpose of the paper was to identify definitions of vulnerability across LEPH; the use of synonyms to depict vulnerability was considered as a potential confounding factor. Therefore, including only papers with vulnerability in the abstract and which later discussed vulnerability as a construct in depth allowed for definitions across LEPH to be drawn out and considered. For this reason, papers that failed to discuss vulnerability form a LEPH perspective in the body of the article were also excluded. We agree that some relevant papers may have been excluded due to the vagueness of the term in everyday language use, and restrictions to abstract length and content in some journals. Thus, to some degree, the abstract screening constitutes a limitation. We also acknowledge the relevance of bringing together a unified 'language' for understanding vulnerability as a concept. Still, trying to encapsulate every potential descriptor for vulnerable people would be outside the scope of the current scoping review and could be a piece of work in its own right.

Fourth, although there are some excellent peer reviewed book chapters published, many are also not peer reviewed. Peer reviewed articles are typically reviewed by academics, contain subject-relevant terms, subjected to a thorough assessment process and are targeted at researchers and professionals. Book chapters and non-peer reviewed articles were excluded because they do not always meet these criteria. Due to the heterogeneity of peer review and the absence of a process to identify peer reviewed book chapters, we chose to omit all book chapters from this scoping review. Nonetheless, the decision to include only known peer reviewed sources may have led to unintentional exclusion of some relevant sources.

Considering these limitations, we suggest that subsequent reviews should consider including: publications in languages other than English, grey literature to enable deeper insight into vulnerability assessments from LEPH perspectives; synonyms of vulnerability during the search for relevant articles; and book chapters.

\section{Stage 3: Selecting the studies}

In applying the inclusion and exclusion criteria, boundaries were established which aided in the selection of relevant studies. See Appendix for the CINAHL, MEDLINE, PsycINFO search criteria which we conducted via the EBSCO platform. As limits were not placed on the country of study or publication, studies from different countries were included in the review. Thus, vulnerability definitions and assessments could be identified from different geographical contexts, enabling analytical breadth and international relevance.

\section{Stage 4: Conducting content analysis}

Relevant articles were exported from CINAHL, MEDLINE, PsycINFO, Criminology Collection, and Sociology Collection into Endnote reference management software for storage and referral purposes. Following title and abstract screening, the remaining papers were subsequently exported to NVivo (qualitative data analysis software), to enable effective, efficient and transparent content analysis. Specifically, a Text Search Query was conducted to retrieve discussions on vulnerability. The findings included the following headings:

- Author name and date

- Article title

- Journal name

- Research country

- Research context (Law Enforcement, Public Health, or both)

- Discussions involving definitions of vulnerability and brief descriptions of vulnerability assessment, if any

- Vulnerability associations

- Research gaps.

\section{Stage 5: Recording, organising and summarising the result Recording the result}

As indicated in Fig. 1, 155 records were identified by searching through the five key databases. Eight duplicates were removed. Following the application of the inclusion and exclusion criteria, an additional 113 records were removed. Of these 113 records, $30^{4}$ were removed because they were inaccessible, eight because their titles did not align with the research question, and 73 because their abstracts did not refer to 'vulnerable' or 'vulnerability'. After the full paper reading of the remaining papers, two were removed because they failed to address the research question. The 34 remaining records met the inclusion criteria and were considered eligible for screening and content analysis via NVivo 10. The following sections organize the results in terms of vulnerability definitions and vulnerability assessment. 


\section{Organising the Results}

Vulnerability definitions The scoping review revealed that definitions of vulnerability are at best fragmented, with only four of the 34 reviewed articles providing explicit definitions of vulnerability as indicated in Table 2.

Vulnerability assessment The scoping review showed that models for assessing vulnerability lack uniformity across LEPH because it is prioritised differently across these organizations. Tables 3, 4 and 5 show this in more detail. From a Law Enforcement perspective, only one model for vulnerability assessment was identified (See Table 3). It was based on how likely individuals think they may be suitable crime targets, and their ease of accessing social support (Gaitan \& Shen, 2018). The assessment model indicated that vulnerability was associated with poverty and perceptions of risk. From a Public Health perspective, five different models for vulnerability assessment were identified. These include:

- Psychosocial Recovery and Development in East Timor (PRADET) (Amiral et al. (2004)

- Rhodes et al.'s $(2005,2012)$ framework of sociostructural vulnerability

- The use of self-reporting (Thorpe et al., 2011)

- The use of Critical Incident Inventory (CCI) which measures exposure to critical incidents (Ward et al., 2006)
- The use of vulnerability definitions (Whitelock, 2009)

Within this context, vulnerability was associated with mental health, social risk, risk environment, risk of abuse, level of risk, access to health care, experience of abuse, and breakdown. From a LEPH perspective, six different models for vulnerability assessment were identified. They include:

- The use of risk factors like:

- The risk of incarceration or arrest (Beach et al., 2013; Saddichha et al., 2014)

- The risk of homelessness (Beach et al., 2013; Glynn et al., 2014)

- The risk of premature discharge from assertive community treatment (Beach et al., 2013)

- The risk of psychiatric hospitalization (Beach et al., 2013)

- The use of risk factors to identify those at risk of committing acts of terrorism (Cohen, 2016)

- Level of exposure to the risk of traffic-related injuries and death (Damsere-Derry et al., 2017)

- Drug War AIDS/HIV inequities model (Kerr \& Jackson, 2016)

- National improvement reports in prison mental services provided in police stations and courts (Slade et al., 2016)

- Appropriate screening although the type of screening was not specified (Wilson, 2016)

Table 2 Explicit Vulnerability (Vuln) Definitions (4). Presentation of articles with explicit definitions of vulnerability

\begin{tabular}{|c|c|c|c|c|c|}
\hline \# & $\begin{array}{l}\text { Author/ } \\
\text { Name/ } \\
\text { Date }\end{array}$ & Research Country & Research Context & Vuln Definitions & Vuln Associated with \\
\hline 1 & $\begin{array}{l}\text { Damsere- } \\
\text { Derry et } \\
\text { al. (2017) }\end{array}$ & Ghana & $\begin{array}{l}\text { Law Enforcement } \\
\text { (criminal justice) and } \\
\text { Public Health }\end{array}$ & $\begin{array}{l}\text { Vulnerable road users (VRU) are defined as those who are } \\
\text { exposed to the risk of traffic accidents because they lack } \\
\text { protective frames. They include pedestrians (over-speeding), } \\
\text { cyclists and motorcyclists (failure to use helmet). Of the three } \\
\text { groups, pedestrians have higher risks of injuries or deaths } \\
\text { owing to an absence of any protective frame. Cyclists and } \\
\text { motor cyclists are protected to some extent by their } \\
\text { protective clothing and helmets. VRU differ from protected } \\
\text { road users because they are sheltered by their vehicles and } \\
\text { associated devices like airbags, child restraints and seat belts. }\end{array}$ & Risk of death \\
\hline 2 & $\begin{array}{l}\text { McNeil \& } \\
\text { Small } \\
(2014)\end{array}$ & $\begin{array}{l}\text { No specific country - } \\
\text { Systematic Literature } \\
\text { Review and Meta- } \\
\text { Analysis. }\end{array}$ & $\begin{array}{l}\text { LE (safer } \\
\text { environments } \\
\text { interventions); PH }\end{array}$ & $\begin{array}{l}\text { Vulnerable groups defined and identified as injection drug } \\
\text { users. Vulnerability seemed to be used as a synonym for } \\
\text { susceptible For example, "vulnerability to health harms..." } \\
\text { (p.151), and "to drug-related harms" (p.152). }\end{array}$ & $\begin{array}{l}\text { Social and physical risk environments } \\
\text { including contextual factors like social, } \\
\text { environmental and structural factors. }\end{array}$ \\
\hline 3 & $\begin{array}{l}\text { Whitelock } \\
(2009)\end{array}$ & UK & PH (mental health) & $\begin{array}{l}\text { A 'vulnerable adult' is defined as a person 'who is or may be } \\
\text { in need of community care services by reason of mental or } \\
\text { other disability, age or illness; and who is or may be unable } \\
\text { to take care of himself, or unable to protect him or herself } \\
\text { against significant harm or exploitation' (Department of } \\
\text { Health, 2000, pgs. } 8 \text { \& 9). Vulnerable adult identified as those } \\
\text { with mental health challenges at risk of abuse within mental } \\
\text { health wards and their communities }\end{array}$ & $\begin{array}{l}\text { Feeling at risk of abuse, level of risk, } \\
\text { experience of abuse, breakdown, }\end{array}$ \\
\hline 4 & $\begin{array}{l}\text { Wilson } \\
(2016)\end{array}$ & Australia & $\begin{array}{l}\text { LE (criminal justice - } \\
\text { police, court } \\
\text { services); PH (social } \\
\text { care) }\end{array}$ & $\begin{array}{l}\text { Vulnerability defined based on age, adaptive behaviour, IQ, } \\
\text { inappropriate agreement to irrational requests (Nettlebeck \& } \\
\text { Wilson, 2002). }\end{array}$ & Weakness and helplessness \\
\hline
\end{tabular}


Table 3 Models for Assessing Vulnerability (Vuln) - Law Enforcement Perspective. Presentation of articles containing models for assessing vulnerability from a Law Enforcement perspective

\begin{tabular}{|c|c|c|c|c|c|}
\hline \# & $\begin{array}{l}\text { Author/ } \\
\text { Name/ } \\
\text { Date }\end{array}$ & $\begin{array}{l}\text { Research } \\
\text { Country }\end{array}$ & $\begin{array}{l}\text { Research } \\
\text { Context }\end{array}$ & Model(s) for Vuln Assessment & Vuln Associated with \\
\hline 1 & $\begin{array}{l}\text { Gaitan \& } \\
\text { Shen } \\
(2018)\end{array}$ & Mexico & $\begin{array}{l}\text { LE } \\
\text { (Criminal } \\
\text { Justice) }\end{array}$ & $\begin{array}{l}\text { Vulnerability assessed based on general indicators like the } \\
\text { individual's perceptions as suitable crime targets, inadequate } \\
\text { social support, and incivilities. }\end{array}$ & $\begin{array}{l}\text { Poverty. Vulnerability associated with reduced } \\
\text { sense of well-being manifested as poverty. Feel- } \\
\text { ings of vulnerability reduced/dissipated by the } \\
\text { perception of increased social cohesion and ac- } \\
\text { cessible social resources. Recursive and intercon- } \\
\text { nected relationship between behaviour on one } \\
\text { hand and vulnerability and risk perceptions on } \\
\text { the other hand. }\end{array}$ \\
\hline
\end{tabular}

According to our findings, the countries with models for assessing vulnerability were Australia, Canada, East Timor, Ghana, Northern and Southern America (Mexico), South Africa and the UK. This is captured in Tables 3, 4 and 5 .

Despite the varying models of assessment across $\mathrm{LEPH}$, the use of risk factors to assess vulnerability appeared in three of the six models identified, as captured in Table 5. From this perspective, vulnerability was associated with forensic histories and high-risk population, risk of death, HIV, mental health, feelings of weakness and helplessness.

\section{Summarising and discussing the results}

As illustrated in Table 6, the current review reveals conflicting priorities across LEPH in relation to vulnerability. Essentially, vulnerability is context-specific from a Law Enforcement perspective, and person-specific from a Public Health perspective.

Table 4 Models for Assessing Vulnerability (Vuln) - Public Health Perspective. Presentation of articles containing models for assessing vulnerability from a Public Health perspective

\begin{tabular}{|c|c|c|c|c|c|}
\hline$\#$ & $\begin{array}{l}\text { Author/ } \\
\text { Name/ } \\
\text { Date }\end{array}$ & Research Country & Research Context & Model(s) for Vuln Assessment & Vuln Associated with \\
\hline 1 & $\begin{array}{l}\text { Amiral et } \\
\text { al. (2004) }\end{array}$ & $\begin{array}{l}\text { East Timore (Post-emergency } \\
\text { phase within post-conflict and } \\
\text { post-war, low-income developing } \\
\text { countries) }\end{array}$ & PH - Mental Health & $\begin{array}{l}\text { The PRADET (Psychosocial recovery and } \\
\text { Development in East Timor) was established to } \\
\text { assess social vulnerabilities in mental health } \\
\text { patients within post-emergency, post-conflict } \\
\text { and post-war East Timore. }\end{array}$ & $\begin{array}{l}\text { Mental disturbances } \\
\text { and social risk }\end{array}$ \\
\hline 2 & $\begin{array}{l}\text { Knight et } \\
\text { al. (2014) }\end{array}$ & US - San Francisco & PH - Mental Health & $\begin{array}{l}\text { Rhodes et al.'s }(2005,2012) \text { framework of socio- } \\
\text { structural vulnerability (p.8). The authors have } \\
\text { adapted the framework to assesses how single } \\
\text { room occupancy hotels affect the mental health } \\
\text { of women in their capacity as "mental health risk } \\
\text { environments" }\end{array}$ & Risk environment \\
\hline 3 & $\begin{array}{l}\text { Thorpe et } \\
\text { al. (2011) }\end{array}$ & US - Wisconsin & PH- Healthcare Access & $\begin{array}{l}\text { Use of self-report to assess vulnerable elderly } \\
\text { people with mental health issues or functional } \\
\text { disabilities. Self-report was administered by doc- } \\
\text { tors who asked questions that enabled them } \\
\text { identify conditions related to mental health is- } \\
\text { sues. The Health Utilities Index Mark III is used to } \\
\text { assess functional health disabilities. Dichotomous } \\
\text { variables signifying the existence of reported lim- } \\
\text { itations regarding cognition, dexterity, hearing, } \\
\text { speech, ambulation and pain were created by } \\
\text { the authors. }\end{array}$ & Access to healthcare \\
\hline 4 & $\begin{array}{l}\text { Ward et } \\
\text { al. (2006) }\end{array}$ & South Africa & $\begin{array}{l}\text { PH - Prehospital } \\
\text { emergency and } \\
\text { associated mental } \\
\text { health outcomes }\end{array}$ & $\begin{array}{l}\text { Exposure to critical incidents assessed by the } \\
\text { authors using f, which is a 22-point scale. The } \\
\text { Revised Impact of Event Scale was used after the } \\
\text { CIl to assess post-traumatic stress disorder } \\
\text { (PTSD). }\end{array}$ & $\begin{array}{l}\text { Critical incident } \\
\text { disorder and PTSD }\end{array}$ \\
\hline 5 & $\begin{array}{l}\text { Whitelock } \\
\text { (2009) }\end{array}$ & UK & PH - Mental Health & $\begin{array}{l}\text { Vulnerability assess based on the vulnerability } \\
\text { definition provided in the No Secrets Guidance } \\
\text { of the Department of Health which considers } \\
\text { people's identity, diagnosis, personal } \\
\text { characteristics or service eligibility. }\end{array}$ & $\begin{array}{l}\text { Feeling at risk of } \\
\text { abuse, level of risk, } \\
\text { experience of abuse, } \\
\text { breakdown, }\end{array}$ \\
\hline
\end{tabular}


Table 5 Models for Assessing Vulnerability (Vuln) - LEPH. Presentation of articles containing models for assessing vulnerability from Law Enforcement and Public Health perspectives

\begin{tabular}{|c|c|c|c|c|c|}
\hline \# & $\begin{array}{l}\text { Author/ } \\
\text { Name/ } \\
\text { Date }\end{array}$ & $\begin{array}{l}\text { Research } \\
\text { Country }\end{array}$ & Research Context & Model(s) for Vuln Assessment & Vuln Associated with \\
\hline 1 & $\begin{array}{l}\text { Beach et } \\
\text { al. (2013) }\end{array}$ & $\begin{array}{l}\text { US - New } \\
\text { York }\end{array}$ & $\begin{array}{l}\text { LE (arrest, incarceration, } \\
\text { forensic, community } \\
\text { treatment); PH (psychiatric } \\
\text { hospitalization) }\end{array}$ & $\begin{array}{l}\text { Four risk factors used to assess and predict } \\
\text { vulnerability. They include the risk of } \\
\text { incarceration or arrest, homelessness, } \\
\text { premature discharge from assertive } \\
\text { community treatment, psychiatric } \\
\text { hospitalization. }\end{array}$ & Forensic histories and high-risk population. \\
\hline 2 & $\begin{array}{l}\text { Cohen } \\
(2016)\end{array}$ & US & $\begin{array}{l}\text { LE (counter-terrorism, } \\
\text { homeland security); PH } \\
\text { (mental health) }\end{array}$ & $\begin{array}{l}\text { The prevention approach which is currently } \\
\text { adopted by some local communities. It } \\
\text { assesses vulnerable individuals by identifying } \\
\text { those at risk of committing acts of terrorism } \\
\text { and intervenes before it happens. Law } \\
\text { enforcement encouraged to work with } \\
\text { mental health at this early stage. (Risk } \\
\text { management and collaborative working - } \\
\text { co-creation of value) }\end{array}$ & $\begin{array}{l}\text { The paper recommends that investigative } \\
\text { and violence prevention protocols by } \\
\text { federal agents should include behavioural } \\
\text { risk assessment techniques. Also } \\
\text { multidisciplinary teams comprising } \\
\text { community, law enforcement, and mental } \\
\text { health should be established to encourage } \\
\text { holistic, structured and cohesive } \\
\text { collaboration. }\end{array}$ \\
\hline 3 & $\begin{array}{l}\text { Damsere- } \\
\text { Derry et } \\
\text { al. (2017) }\end{array}$ & Ghana & LE (police); PH & $\begin{array}{l}\text { Vulnerability assessed based on level of } \\
\text { exposure to the risk of traffic-related injuries } \\
\text { and death. }\end{array}$ & Risk of death \\
\hline 4 & $\begin{array}{l}\text { Kerr \& } \\
\text { Jackson } \\
\text { (2016) }\end{array}$ & US & $\begin{array}{l}\text { LE (Criminal Justice - } \\
\text { inequitable sentencing and } \\
\text { policing); PH (Impact of drug } \\
\text { war on HIV vulnerability) }\end{array}$ & $\begin{array}{l}\text { Based on three pathways, the authors } \\
\text { developed a Drug War AIDS/HIV inequities } \\
\text { model developed to assess how HIV } \\
\text { vulnerability in African Americans can } \\
\text { increase as a result of the drug war. The } \\
\text { pathways are sexual networking, social } \\
\text { marginalization and resource deprivation. }\end{array}$ & HIV \\
\hline 5 & $\begin{array}{l}\text { Slade et } \\
\text { al. (2016) }\end{array}$ & $\begin{array}{l}\text { UK - } \\
\text { England } \\
\text { and } \\
\text { Wales }\end{array}$ & $\begin{array}{l}\text { LE (Criminal Justice); PH } \\
\text { (mental health) }\end{array}$ & $\begin{array}{l}\text { Mental health vulnerability assessed via the } \\
\text { National improvements in prison mental } \\
\text { health services, and diversion and liaison } \\
\text { services provided in police stations and } \\
\text { courts. Based on clinical need, liaison } \\
\text { services include communications with } \\
\text { hospitals, communities, or prison services. } \\
\text { Diversion services involves referring } \\
\text { identified vulnerable groups to either a } \\
\text { hospital bed or community service. }\end{array}$ & Mental health disturbances \\
\hline 6 & $\begin{array}{l}\text { Wilson } \\
\text { (2016) }\end{array}$ & Australia & $\begin{array}{l}\text { LE (criminal justice - police, } \\
\text { court services); PH (social care) }\end{array}$ & $\begin{array}{l}\text { Appropriate screening, Vulnerability was also } \\
\text { assessed using the Social Vulnerability } \\
\text { Questionnaire, developed by Fisher, } \\
\text { Moskowitz, \& Hodapp, 2012; the Test of } \\
\text { Interpersonal Competence and Personal } \\
\text { Vulnerability, developed by Wilson, Seaman, } \\
\text { \& Nettelbeck, 1996; and the Decision-making } \\
\text { Video Scale, developed by Hickson, Khemka, } \\
\text { Golden, \& Chatzistyli, 2008. }\end{array}$ & Weakness and helplessness \\
\hline
\end{tabular}

Table 6 LEPH Conflicting Priorities on Vulnerability (Vuln) Issues. Presentation of articles evidencing conflicting priorities across LEPH as regards vulnerability

\begin{tabular}{lllll}
\hline \# & Law Enforcement & References & Public Health & References \\
\hline 1 & Criminal Justice & $\begin{array}{l}\text { Frye and Dawe (2008); Saddichha et al. (2014); Pinedo et al. } \\
\text { (2017); Gaitan \& Shen (2018); Hyatt \& Han (2018) }\end{array}$ & $\begin{array}{l}\text { Physical Health } \\
\text { (HIV) }\end{array}$ & $\begin{array}{l}\text { Simic \& Rhodes (2009); Syvertsen et al. } \\
\text { (2014); Forbes (2015) }\end{array}$ \\
2 Hostage Taking & Ludwig-Barron et al. (2015) & Mental Health & $\begin{array}{l}\text { Amiral et al. (2004); Ward et al. (2006); } \\
\text { Whitelock (2009); Knight et al. (2014) }\end{array}$ \\
$\begin{array}{llll}\text { Intimate Partner } \\
\text { Violence }\end{array}$ & Ludwig-Barron et al. (2015) & $\begin{array}{l}\text { Paramedics/ Pre- } \\
\text { hospital Emergency }\end{array}$ & Ward et al. (2006) \\
$\begin{array}{l}\text { Racial Profiling and } \\
\text { Traffic Stop Risk }\end{array}$ & Miller (2009) & Healthcare Access & Thorpe et al. (2011) \\
\hline
\end{tabular}


Studies and discussions on vulnerability from a Law Enforcement perspective revolved around contextual issues. These related to criminal justice, hostage taking, intimate partner violence, racial profiling and traffic stop risk. These issues relate to a specific circumstance, situation and/or place (Table 6). On the other hand, vulnerability studies and discussions from a Public Health perspective addressed personal matters. These relate to patients' physical health, mental health and access to pre-hospital emergency services and/or health care (Table 6).

At the intersect of LEPH, the selected studies looked at a range of criminal justice and public health issues in tandem. As captured in Table 7, these include but are not limited to policing practices police contact/custody, inequitable sentencing, arrest, incarceration/correctional setting, community treatment, psychiatric hospitalization, parole, forensic, counter-terrorism, victimisation, public health systems, learning disabilities, drug users, court cases, social care and others.

Essentially, the studies demonstrated that the concept of vulnerability from a LEPH perspective was wide; extending well beyond the concept of mental health. This probably explains the inconsistencies and lack of explicitness in vulnerability definitions and assessments across LEPH. Likewise, the studies captured in Table 7 confirm that partnership working between policing and public health is unavoidable and necessary.

\section{Stage 6: Stakeholder engagement}

Stakeholder engagement in this project was in the form of an Expert Advisory Group (EAG). This collaborative partnership comprises 26 individuals within senior roles across LEPH organisations in Scotland, including: Directors, Co-Directors, and Professors of Law Enforcement and Public Health; senior Officers in Police Scotland; senior Public Health Officials across psychiatry, emergency medicine, and substance misuse; Senior members in the Scottish Government; Senior members of voluntary sector organisations and those with lived experience; and academics and researchers working across criminal justice, psychology, health, and vulnerability. The primary purpose of the EAG is to "to inform and support the development of a co-constructed programme of research crossing the intersect of Law Enforcement and Public Health" (Murray et al., 2018, p.1). A follow up EAG vulnerability sub-committee meeting was held to specifically inform the search strategy and research question for the current review, and to identify possible future steps

Table 7 Vulnerability-related issues at the Intersect of LEPH. Presentation of articles discussing vulnerability-related issues at the intersct of LEPH organisations

\begin{tabular}{|c|c|c|}
\hline \# & Law Enforcement \& Public Health & References \\
\hline 1 & Arrest, incarceration, forensic, community treatment, psychiatric hospitalization & Beach et al. (2013) \\
\hline 2 & Policy and public health & Boeri et al (2009) \\
\hline 3 & Criminal justice and paramedics & Borschmann et al. (2017) \\
\hline 4 & Counter-terrorism, homeland security, mental health & Cohen (2016) \\
\hline 5 & Traffic injury prevention & Damsere-Derry et al. (2017) \\
\hline 6 & Criminal justice and mental health & Ferrazzi \& Krupa (2016) \\
\hline 7 & Correctional setting and physical health (HIV) & Frisman et al (2008) \\
\hline 8 & Correctional setting and mental health (dementia and cognitive impairment) & Gaston (2018) \\
\hline 9 & Criminal justice, public health systems and clinicians & Glynn et al (2014) \\
\hline 10 & Parole, probation and drug addictive behaviours & Hall et al (2016) \\
\hline 11 & Inequitable sentencing, impact of drug war on HIV vulnerability & Kerr and Jackson (2016) \\
\hline 12 & Safer environments and drug users & McNeil \& Small (2014) \\
\hline 13 & Crime and mental health & Morrall et al (2010) \\
\hline 14 & Policing practices and drug injecting deported migrants & Pinedo et al. (2017) \\
\hline 15 & Incarceration, substance abuse and mental health & Saddichha et al. (2014) \\
\hline 16 & Violence, abuse, learning disabilities & Olszowski \& Boaden et al (2010) \\
\hline 18 & Incarceration and mental health & Slade et al. (2016) \\
\hline 19 & Incarcerated rural women, mental health, HIV & Staton-Tindall et al (2015) \\
\hline 20 & Police contact, police custody, mental health (cognitive disability) & Trofimovs \& Dowse (2014) \\
\hline 21 & Victimisation, court services and social care & Wilson (2016) \\
\hline 22 & Learning Disability and risk of criminality & Allen (2007) \\
\hline
\end{tabular}


and areas for research which would be a priority in LEPH practice.

\section{Concluding remarks}

Considering LEPH organisations, this review aimed to identify the ways in which vulnerability is defined and assessed across adult populations. The implications of the findings of the current scoping review are two-fold. For "vulnerable groups", the lack of an evidence-based definition and assessment could introduce a raft of problems. These include preventing access to relevant LEPH services; exacerbating issues of multiple vulnerabilities, co-morbidity, and/or dual diagnosis; and impeding effective communication across LEPH partners. All could inadvertently enable the social exclusion of vulnerable groups from political discourse and policy interventions. For LEPH organizations and, by extension, Federal Governments, the inconsistencies in vulnerability definitions and assessments may result in reactive crisis responses as opposed to proactive preventative measures.

During the scoping review, research gaps were identified. From a co-production and social innovation perspective, Whitelock (2009) identified the absence of a personalised definition of vulnerability. The author stressed the need to develop one that includes the service user's voice as a critical step towards the care planning and support process. Similarly, Forbes (2015) argued for the need to explicitly identify marginalised sex-workers as vulnerable people. This may increase their chances of being included in political health discourse and could facilitate the development of effective care pathways.

Considering mental health issues, Borschmann et al. (2017) noted the need for further research on clinical management and epidemiology of reactions to self-harm, clinical outcomes and care pathways for vulnerable patients. Likewise, Cohen (36) noted the absence of behavioural risk assessment techniques and recommended that terrorism violence prevention protocols should include such. Recommendations also included the need for more multidisciplinary teams across community, policing and mental health to encourage holistic and structured collaboration and co-production of services (Cohen, 2016).

From an academic perspective, the scoping study clearly exposes the complexities associated with defining and assessing vulnerability across LEPH. This may be because they are perceived and prioritised differently in both organizations. Future research should attempt to bridge this gap. This could assume the form of a Systematic Literature Review to identify effective models that are currently used to assess vulnerability in LEPH practice. This would be useful in both academia and in practice. The proposed Systematic Literature Review should form the basis of any future intervention or vulnerability/risk assessment development work to ensure rigour and sound operational and theoretical underpinnings. A synthesis of vulnerability models would enable the development of a vulnerability and mental health assessment framework, for example, which could then be tested across LEPH practice.

The Scoping Review also highlights the challenges associated with implementing a universal definition of vulnerability across LEPH organisations. Considering that the goal is to find some commonality with "vulnerable" groups along with policy (Police Scotland, 2017; Van Dijk \& Crofts, 2017; Punch \& James, 2016), this proposed universal definition would have to be agreed upon by both law enforcement and public health areas since they are two separate entities. We believe that a universal definition would be helpful for a range of law enforcement and public health services and treatment, including the police, courts, control rooms and emergency healthcare. From a LEPH perspective, a universal definition of vulnerability can facilitate universal vulnerability assessment, decision-making processes, and understanding of problems faced across LEPH. Basically, with a shared language in the first instance, and shared understanding of each organisation's role in the 'system, shared decision-making protocols and processes, can be developed. This increases the likelihood of successful and effective partnership working across LEPH.

Ultimately, the ambition is the development of properly linked services, which respect and understand each organisation's role, strength and limitation, and which takes cognizance of mental health and vulnerability issues. Of course, a whole-systems approach to LEPH is ambitious, but we feel that taking it step by step, starting with shared understanding and definitions is a good step forward, together, across the intersect of LEPH. Also, existing assessment models may need to be reviewed and revised to capture the new, more universal definition of vulnerability if or when it is developed.

\section{Endnotes}

${ }^{1}$ To understand how and why a term is used, by whom and in what literature.

${ }^{2}$ To carve out relevant literature according to scope. Usually involves synthesizing findings from various studies.

${ }^{3}$ To identify key documents from the public and private sector that concern practice in the related sector.

${ }^{4}$ The cases were excluded after efforts to retrieve them using three Scottish University Library subscriptions (Edinburgh Napier University, Glasgow Caledonian University, University of Edinburgh), google scholar and 


\section{Appendix}

Table 8 CINAHL/MEDLINE/PsychINFO Search strategy - August 2018

\begin{tabular}{|c|c|c|}
\hline \# & Query & $\begin{array}{l}\text { Results } \\
\text { (N Papers }\end{array}$ \\
\hline 1 & $A B$ law enforcement $O R A B$ police $O R A B$ policing $O R A B$ criminal justice & 57,862 \\
\hline 2 & $A B$ public health $O R A B$ mental health $O R A B$ disparity & 650,689 \\
\hline 3 & $A B$ social determinants of health $O R A B$ socioeconomic factors $O R A B$ social inequality $O R A B$ inequality & 72,184 \\
\hline 4 & $A B$ adult protective services $O R A B$ adult protection $O R A B$ incapacity $O R A B$ learning disability $O R A B$ learning disorder & 38,771 \\
\hline 5 & S2 OR S3 OR S4 & 743,471 \\
\hline 6 & $A B$ vulnerab* $O R A B$ access & 583,379 \\
\hline 7 & $A B$ risk* $O R A B$ at risk & $2,526,889$ \\
\hline 8 & S1 AND S5 AND S6 AND S7 & 29 \\
\hline
\end{tabular}

google search engine failed to provide access to these papers. The decision to include papers that could be reasonably accessed was contingent on the fact that LEPH professionals would likely have even less institutional access to peer reviewed papers. We therefore considered these 30 papers inaccessible to most academics and those working in LEPH practice.

\section{Acknowledgements}

The authors are grateful for the guidance provided by Sheena Moffat, Edinburgh Napier University's Subject Librarian within the School of Health and Social Care, during the design and development of the Search Strategy for the Scoping Review. The authors would also like to thank Police Scotland for their support during the funding application process and throughout the project. In particular, ACC John Hawkins and Chief Inspector Rosie Wright for their insight throughout the development and conduct of the study. The project has also benefitted from an international expert advisory group across LEPH who supported the project team to identify vulnerability-related issues as a shared organisational challenge and a key research priority within the LEPH intersect. As a result, they articulated and provided clarity on the research aim and significance to LEPH organisations, service users, and Governments.

\section{Funding}

This research was funded by the Scottish Institute of Policing Research. Senior officers within Police Scotland were involved at all stages of the project. They identified vulnerability-related issues as a shared organisational challenge and a key research priority within the LEPH intersect. As a result, they articulated and provided clarity on the research aim and significance to LEPH organisations, service users, and Governments.

\section{Availability of data and materials}

Not applicable.

\section{Authors' contributions}

IE led the development of the search strategy, inclusion and exclusion criteria, managed the day to day running of the project and synthesised the data. IE prepared the first and final drafts of the manuscript. JM was the PI on the project and liaised closely with colleagues at Police Scotland during the early stages of the project's funding application and with IE to develop the search strategy and inclusion/exclusion criteria. JM led the writing of the funding application and contributed to the writing of the drafts of the manuscripts and the final draft. ND provided support and guidance to the team as the senior-most colleague from a public health perspective to ensure the project's relevancy to health settings. ND contributed towards the writing of the draft of the manuscript and supported IE in the data selection stages. AW helped to develop the funding application, the research design, and was involved in shaping the paper providing feedback on the manuscript at key time points. IH was Co-PI on the funding application and was central in gaining the connections and insight of the expert advisory group, which was absolutely central to the design of the study and its focus. IH supported IE in the inclusion and exclusion criteria, with a focus on relevant legislation, and contributed to the drafting of the manuscript via feedback. EG contributed towards the development of the funding application, discussions with the research team at key time points and throughout the project and with the expert advisory group regarding the focus of the study and the manuscript and provided feedback on the manuscript drafts. I will be serving as corresponding author for this manuscript. All of the authors listed in the by-line have agreed to the by-line order and to submission of the manuscript in this form. I have assumed responsibility for keeping my co-authors informed of our progress through the editorial review process, the content of the reviews, and any revisions made.

Ethics approval and consent to participate

Not applicable

\section{Consent for publication}

Not applicable

\section{Competing interests}

Four of the authors (ND, JM, IH, IE) contributed a response to the Scottish Government's Suicide Prevention Action Plan (2018), and IH provided extensive input into the Scottish Government's 2018 Collaborative Police and Health Interventions for Mental Health Distress report. EA became the Director of the Scottish Institute of Policing Research after the project began. While these are not directly related to the current project or its outcomes, we feel that they are within the same policy-vein and should be declared.

\section{Publisher's Note}

Springer Nature remains neutral with regard to jurisdictional claims in published maps and institutional affiliations.

\section{Author details}

${ }^{1}$ School of Health \& Social Care, Edinburgh Napier University, Sighthill Campus, Sighthill Court, Edinburgh EH11 4BN, Scotland, UK. ${ }^{2}$ School of Applied Sciences, Edinburgh Napier University, Sighthill Campus, Sighthill Court, Edinburgh EH11 4BN, Scotland, UK.

Received: 17 September 2018 Accepted: 12 February 2019

Published online: 01 March 2019

\section{References}

Allen, D. (2007). Inside story. Learning Disability Practice.

Amiral, Z. F., Baker, K., de Carvalho, F., Manicavasagar, V., Mausiri, M., Silove, D., \& Soares, M. (2004). Indices of social risk among first attenders of an emergency mental health service in post-conflict East Timor: An exploratory investigation. Australian and New Zealand Journal of Psychiatry, 38(11/12), 929-933.

Anderson, S. Allen, P., Peckham, S. \& Goodwin, N. (2008). Asking the right questions: Scoping studies in the commissioning of research on the 
organisation and delivery of health services. Health Research Policy and Systems, 6(1), 7

Arksey, H., \& O'Malley, L. (2005). Scoping studies: Towards a methodological framework. International Journal of Social Research Methodology, 8(1), 19-32.

Beach, C., Dykema, L.-R., Appelbaum, P. S., Deng, L., Leckman-Westin, E., Manuel, J. I., \& Finnerty, M. T. (2013). Forensic and nonforensic clients in assertive community treatment: A longitudinal study. Psychiatric Services, 64(5), 437444. https://doi.org/10.1176/appi.ps.201200170.

Borschmann, R., Young, J., Moran, P., Spittal, M., Heffernan, E., Mok, K., \& Kinner, S. A. (2017). Ambulance attendances resulting from self-harm after release from prison: A prospective data linkage study. Social Psychiatry \& Psychiatric Epidemiology, 52(10), 1295-1305. https://doi.org/10.1007/s00127-017-1383-z.

Care Information Scotland. (2018). Adult support and protection (Scotland) Act 2007. Retrieved from https://www.careinfoscotland.scot/topics/your-rights/ legislation-protecting-people-in-care/adult-support-and-protection-scotlandact-2007/ [2018, September 3]

Cohen, J. D. (2016). The next generation of government CVE strategies at home. Annals of the American Academy of Political and Social Science, 668(1), 118128. https://doi.org/10.1177/0002716216669933.

College of Policing. (2018). Mental health: Mental health vulnerability and illness. Retrieved from https://www.app.college.police.uk/appcontent/mental-health/ mental-vulnerability-and illness/[2018, September 3].

Damsere-Derry, J., Palk, G., \& King, M. (2017). Road accident fatality risks for "vulnerable" versus "protected" road users in northern Ghana. Traffic Injury Prevention, 18(7), 736-743. https://doi.org/10.1080/15389588.2017.1302083.

Department of Health. (2014). Mental health crisis care concordat: Improving outcomes for people experiencing mental health crisis.

Ehrich, K., Freeman, G. K., Richards, S. C., Robinson, I. C., \& Shepperd, S. (2002). How to do a scoping exercise: Continuity of care. Research, Policy and Planning, 20(1), 25-29.

Fisher, M. H., Moskowitz, A. L., \& Hodapp, R. M. (2012). Vulnerability and experiences related to social victimization among individuals with intellectual and developmental disabilities. Journal of Mental Health Research in Intellectual Disabilities, 5(1), 32-48.

Forbes, A. (2015). Speaking of sex workers: How suppression of research has distorted the United States' domestic HIV response. Reproductive Health Matters, 23(45), 21-29. https://doi.org/10.1016/j.rhm.2015.06.008.

Frye, S., \& Dawe, S. (2008). Interventions for women prisoners and their children in the post-release period. Clinical Psychologist, 12(3), 99-108. https://doi.org/ 10.1080/13284200802516522.

Gaitán-Rossi, P., \& Shen, C. (2018). Fear of crime in Mexico: The impacts of municipality characteristics. Social Indicators Research, 135(1), 373-399. https://doi.org/10.1007/s11205-016-1488-x.

Gaston, S. (2018). Vulnerable prisoners: Dementia and the impact on prisoners, staff and the correctional setting. Collegian, 25(2), 241-246.

Glynn, L., Kendra, M., Timko, C., Finlay, A., Blodgett, J., Maisel, N., Midboe, A., McGuire, J., \& Blonigen, D. (2014). Facilitating treatment access and engagement for justice-involved veterans with substance use disorders. Criminal Justice Policy Review, 27(2), 138-163.

Grant, M. J., \& Booth, A. (2009). A typology of reviews: An analysis of 14 review types and associated methodologies. Health Information \& Libraries Journal, 26(2), 91-108.

Hall, M. T., Golder, S., Higgins, G. E., \& Logan, T. K. (2016). Nonmedical prescription opioid use among victimized women on probation and parole. Addictive Behaviors; Addictive Behaviors, 53, 113-119. https://doi.org/10.1016/j.addbeh. 2015.10.008.

Hickson, L., Khemka, I., Golden, H., \& Chatzistyli, A. (2008). Profiles of women who have mental retardation with and without a documented history of abuse. American Journal on Mental Retardation, 113(2), 133-142.

Hyatt, J., \& Han, S. (2018). Expanding the focus of correctional evaluations beyond recidivism: The impact of halfway houses on public safety. Journal of Experimental Criminology, 14(2), 187-211. https:/doi.org/10.1007/s11292-018-9326-6.

Kerr, J., \& Jackson, T. (2016). Stigma, sexual risks, and the war on drugs: Examining drug policy and HIV/AIDS inequities among African Americans using the drug war HIV/AIDS inequities model. The. The International Journal on Drug Policy, 37, 31

Knight, K. R., Lopez, A. M., Comfort, M., Shumway, M., Cohen, J., \& Riley, E. D. (2014). Single room occupancy (SRO) hotels as mental health risk environments among impoverished women: The intersection of policy, drug use, trauma, and urban space. The The International Journal on Drug Policy, 25(3), 556.
Larkin, M. (2009). Vulnerable groups in health and social care. London: Sage Publications Ltd.

Levac, D., Colquhoun, H., \& O'Brien, K. K. (2010). Scoping studies: Advancing the methodology. Implementation Science, 5(1), 69.

Ludwig-Barron, N., Syvertsen, J. L., Lagare, T., Palinkas, L. A., \& Stockman, J. K. (2015). Live to tell: Narratives of methamphetamineusing women taken hostage by their intimate partners in San Diego, CA. The International Journal on Drug Policy, 26(9), 843. https://doi.org/10.1016/j.drugpo.2015.05.012.

McNeil, R., \& Small, W. (2014). 'Safer environment interventions': A qualitative synthesis of the experiences and perceptions of people who inject drugs. Social Science \& Medicine, 106, 151.

Miller, K. (2009). Race, driving, and police organization: Modeling moving and nonmoving traffic stops with citizen self-reports of driving practices. Journal of Criminal Justice, 37(6), 564-575. https://doi.org/10.1016/j.jcrimjus.2009.09. 005

Morrall, P., Marshall, P., Pattison, S., \& Macdonald, G. (2010). Crime and health: A preliminary study into the effects of crime on the mental health of UK university students. Journal of Psychiatric and Mental Health Nursing, 17(9), 821-828. https://doi.org/10.1111/j.1365-2850.2010.01594.x.

Murray, J., Heyman, I., Wooff, A., Dougall, N., Aston, L., \& Enang, I. (2018). Law enforcement and public health: Setting the agenda for Scotland. Scottish Institute for Policing Research Annual Review.

Nettelbeck, T., \& Wilson, C. (2002). Personal vulnerability to victimization of people with mental retardation. Trauma, Violence, \& Abuse, 3(4), 289-306.

Olszowski, P., \& Boaden, A. (2010). Targeted violence, harassment and abuse against people with learning disabilities in great britain. Tizard Learning Disability Review, 15(1), 28-30. https://doi.org/10.5042/tldr.2010.0027.

Pinedo, M., Beletsky, L., Alamillo, N., \& Ojeda, V. (2017). Health-damaging policing practices among persons who inject drugs in Mexico: Are deported migrants at greater risk? The International Journal on Drug Policy, 46, 41.

Police Scotland. (2017). Policing 2026: Our 10 year strategy for policing in Scotland Retrieved from http://www.scotland.police.uk/assets/pdf/138327/ 386688/policing-2026-strategy.pdf [2018, September 4].

Punch, M., \& James, S. (2017). Researching law enforcement and public health. Policing and Society, 27(3), 251-260. https://doi.org/10.1080/10439463.2016. 1205066.

Rhodes, T., Singer, M., Bourgois, P., Friedman, S. R., \& Strathdee, S. A. (2005). The social structural production of HIV risk among injecting drug users. Social Science \& Medicine, 61(5), 1026-1044.

Rhodes, T., Wagner, K., Strathdee, S. A., Shannon, K., Davidson, P., \& Bourgois, P. (2012). Structural violence and structural vulnerability within the risk environment: Theoretical and methodological perspectives for a social epidemiology of HIV risk among injection drug users and sex workers. In Rethinking social epidemiology: Towards a science of change (Vol 9789400721388) (pp. 205-230). Springer Netherlands.

Saddichha, S., Fliers, J. M., Frankish, J., Somers, J., Schuetz, C. G., \& Krausz, M. R. (2014). Homeless and incarcerated: An epidemiological study from Canada. International Journal of Social Psychiatry, 60(8), 795-800. https://doi.org/10. $1177 / 0020764014522776$.

Simić, M., \& Rhodes, T. (2009). Violence, dignity and HIV vulnerability: Street sex work in Serbia. Sociology of Health \& IIIness, 31(1), 1-16. https://doi.org/10. 1111/j.1467-9566.2008.01112.x.

Slade, K., Samele, C., Valmaggia, L., \& Forrester, A. (2016). Pathways through the criminal justice system for prisoners with acute and serious mental illness. Journal of Forensic \& Legal Medicine, 44, 162-168. https://doi.org/10.1016/j. jflm.2016.10.007.

Staton-Tindall, M., Harp, K. L. H., Minieri, A., Oser, C., Webster, J. M., Havens, J., \& Leukefeld, C. (2015). An exploratory study of mental health and HIV risk behavior among drug-using rural women in jail. Psychiatric Rehabilitation Journal, 38(1), 45-54

Syvertsen, J. L., Robertson, A. M., Strathdee, S. A., Martinez, G., Rangel, M. G., \& Wagner, K. D. (2014). Rethinking risk: Gender and injection drug-related HIV risk among female sex workers and their non-commercial partners along the Mexico-U.S. border. International Journal of Drug Policy, 25(5), 836-844. https://doi.org/10.1016/j.drugpo.2014.02.005.

The Scottish Government. (2008). About the adults with incapacity (scotland) act 2000. Retrieved from https://www.gov.scot/Publications/2008/03/25120154/1 [2018, August 27].

The Scottish Government. (2010). The healthcare quality strategy for NHS Scotland. Retrieved from https://www.gov.scot/resource/doc/311667/ 0098354.pdf [2018, August 27]. 
The Scottish Government. (2017). Evaluation of police and fire reform: Year 2 report. Retrieved from https://beta.gov.scot/binaries/content/documents/ govscot/publications/research-publication/2017/08/evaluation-police-firereform-year-2-report/documents/00523031-pdf/00523031-pdf/govscot: document/ [2018, August 27].

The Scottish Government. (2018). Adult support and protection. Retrieved from https://www.gov.scot/Topics/Health/Support-Social-Care/Adult-SupportProtection [2018, August 28].

The Scottish Parliament. (2012). Police and fire reform (scotland) bill. Retrieved from https://www.parliament.scot/S4_Bills/

Police\%20and\%20Fire\%20Reform\%20(Scotland)\%20Bill/Ex_Notes_and_FM.pdf [2018, August 28]

Thorpe, J. M., Thorpe, C. T., Kennelty, K. A., \& Pandhi, N. (2011). Patterns of perceived barriers to medical care in older adults: A latent class analysis. BMC Health Services Research, 11(1), 181. https://doi.org/10.1186/1472-6963-11-181.

Trofimovs, J., \& Dowse, L. (2014). Mental health at the intersections: The impact of complex needs on police contact and custody for indigenous australian men. International Journal of Law and Psychiatry, 37(4). https://doi.org/10. 1016/j.jijp.2014.02.010.

van Dijk, A., \& Crofts, N. (2017). Law enforcement and public health as an emerging field. Policing and Society, 27(3), 261-275.

Ward, C. L., Lombard, C. J., \& Gwebushe, N. (2006). Critical incident exposure in south African emergency services personnel: Prevalence and associated mental health issues. Emergency Medicine Journal, 226-231. https://doi.org/10. 1136/emj.2005.025908.

Whitelock, A. (2009). Safeguarding in mental health: Towards a rights-based approach. The Journal of Adult Protection, 11(4), 30-42. https://doi.org/10. $1108 / 14668203200900026$

Wilson, C. (2016). Victimisation and social vulnerability of adults with intellectual disability: Revisiting Wilson and Brewer (1992) and responding to updated research. Australian Psychologist, 51(1), 73-75. https://doi.org/10.1111/ap. 12202.

Wilson, C., Seaman, L., \& Nettelbeck, T. (1996). Vulnerability to criminal exploitation: Influence of interpersonal competence differences among people with mental retardation. Journal of Intellectual Disability Research, 40 $8-16$.

Ready to submit your research? Choose BMC and benefit from:

- fast, convenient online submission

- thorough peer review by experienced researchers in your field

- rapid publication on acceptance

- support for research data, including large and complex data types

- gold Open Access which fosters wider collaboration and increased citations

- maximum visibility for your research: over $100 \mathrm{M}$ website views per year

At $\mathrm{BMC}$, research is always in progress.

Learn more biomedcentral.com/submissions 